\title{
Introduction - Difficult intersections: \\ Social excellence, equity, and the democratization of higher education
}

\author{
Rosa Bruno-Jofré \\ Queen's University, Canada
}

Encounters/Encuentros/Rencontres on Education underwent important changes in 2014. The journal was renamed Encounters in Theory and History of Education, the design was changed, and following the policies - but with a heavy heart - the Advisory Board was renewed. We are very grateful to all of the members who trusted us in this journey from the beginning, and to the incoming members who expressed a commitment to move Encounters ahead into new territories. As it has been since 2012, Encounters remains the journal of the Theory and History of Education International Research Group. In January, co-founding co-editor Gonzalo Jover (Department of Theory and History of Education, Universidad Complutense de Madrid) left the active editorship to become honorary coeditor after fourteen years of outstanding work with the journal.

The name change responded to a desire to fully focus on theory and history of education in a global space, encouraging an intellectual-inquiry perspective at a time when philosophy and history of education have almost disappeared from teacher education programs. The current practice-driven discourse dominant in teacher education is deprived of the ability to pose fundamental questions related to what is good, desirable, and worthwhile in education; it cannot go to the deep past of central ethical, political, and scientific concepts and their historical contexts. This approach undermines critical analysis and thoughtful reform efforts. In the end, current discourses tend to privilege experience by separating it from theory and foster a deafening presentism, undermining critical analysis even of the construction of subjectivities and thoughtful reform efforts. ${ }^{1}$

The Editorial Team comprises Rosa Bruno-Jofré (co-founding editor); Jon Igelmo Zaldívar (Deusto University, Spain) and Stephanie Mari (an independent researcher) as managing editors; and Carlos Martínez Valle (Universidad Complutense de Madrid) as academic assistant to the editors. The Advisory Board reflects, as it did before, a cosmopolitan landscape of distinguished scholars. To introduce the revitalized Encounters, we made various invited presentations at the local and international level. Jon Igelmo

\footnotetext{
${ }^{1}$ See Current Issues in Education: An Inquisitive Engagement. Education Letter. Faculty of Education, Queen's University (Spring/Summer 2014).
} 
Zaldívar kindly represented us in a couple of them, including a panel entitled "The Open Access Tipping Point: Toward Openness as the Default," as part of the Open Access Week at Queen's University, Canada (October 2014); ${ }^{2}$ as well as at the History of Education Journals Workshop held in Valladolid, Spain (February 2015). ${ }^{3}$ A joint introduction of the journal by the editorial team appears in Hernández Huerta, J. L., Cagnolati, A., \& Diestro Fernández, A. (Eds.). (2015). Connecting History of Education: Scientific Journals as International Tools for a Global World. Salamanca, Spain: FahrenHouse, pp. 47-56. ${ }^{4}$

This issue has been inspired to an important extent by the work of the Network for Excellence in Higher Education (NEHE), created in early 2012 by members (including myself) of the jury appointed by the French Agency for National Research (ANR) to identify the most innovative projects in higher education in France. A book with contributions from the Network members is forthcoming. ${ }^{5}$ NEHE is critical of the elitist notion of excellence grounded in the selection of the best students and professors and meeting the criteria to place high in international rankings. Instead, NEHE advocates an excellence that is at the same time social - providing means to students to be able to reach their own level of excellence, as excellence should not be reserved for a small number of students and professors - and societal - providing students with the skills and knowledge they need to serve as responsible citizens able to read their historical reality.

Dr. Bernard Hugonnier is guest editor for Part I of this issue entitled Network for Excellence in Higher Education (NEHE): The Case for a New Type of 'Excellence.' Dr. Hugonnier, one of the inspiring forces behind NEHE, is former deputy director of OECD (2002-2012), co-director of research at the Collège des Bernardins à Paris, maître de conferences à Sciences-po Paris, and president of Conseils sans frontiers. His introduction provides a substantial frame of reference. Contributors to this part include several other members of the Network: Jean-Marie De Ketele (Catholic University of Louvain, Belgium); Donatella Palomba (University of Rome, Italy); Ana Maria Freitas Teixeira (Federal University of Recôncavo da Bahía, Brazil); and Naomar Monteiro de Almeida Filho (president of the Federal University of Southern Bahia and senior research fellow at the National Research Council of Brazil, as well as the holder of a Doctor of Science honoris causa degree from McGill University). Part I closes with an interview with Naomar de Almeida Filho conducted by Manuel Tavares - editor-in chief of the Lusophone Journal of Education, Lisbon, Portugal - and Tatiana Romão. It is entitled "Emerging Counterhegemonic Models in Higher Education: The Federal University of Southern Bahía (UFSB) and its Contribution to a Renewed Geopolitics of Knowledge." The UFSB represents

\footnotetext{
${ }^{2}$ See http://library.queensu.ca/scholcomm/open-access/OpenAccess2014.

${ }^{3}$ See http://www.espaciotiempoyeducacion.com/ojs/index.php/ete/announcement/view/6.

${ }^{4}$ See http://www.fahrenhouse.com/fh/downloads/category/libros.

${ }^{5}$ De Ketele, J-M., Hugonnier, B., Cosnefroy, L., \& Parmentier, P. (Eds.). (2016, forthcoming). Quelle Excellence pour l'enseignement supérieur. Brussels, Belgium: De Boeck.
} 
a renewed institutional model inspired by the need to reach social excellence and aiming at meeting the current social, political, and economic demands in the southern Bahía state.

Part II is titled Construing the Subject in Higher Education: The Local and the Global, Residual and Emerging Theories, and the Curriculum. It opens with "Individuality as an Educational Project: Kilpatrick, Curriculum Theory, Teacher Education" by well-known curriculum theorist, William F. Pinar (University of British Columbia). This landmark article reconceptualizes teacher education as primarily subjective. It is followed by an article on Waldorf teacher education written by Patricia Quiroga Uceda (Theory and History of Education International Research Group), "Waldorf Teacher Education: Historical Origins, its Current Situation as a Higher Education Training Course, and the Case of Spain." This original work grounded in extensive documentary research and oral testimonies examines the first training courses organized in 1919 by Rudolf Steiner (18611925) within the principles of his anthroposophy. The author then analyzes Waldorf teacher training today and its theoretical underpinnings, and finally focuses on the training course in Spain. The article by Luján Lázaro Herrero, "The Future of Spanish Public Universities: The Challenges of a Discourse of Excellence," takes us to current debates on the role of the Spanish university. Lázaro Herrero uses the report prepared by the Panel of Experts for the Reform of the Spanish University System as a point of reference in his analysis. The work by Catherine Schreiber (University of Luxembourg), "Integrating the Cosmopolitan and the Local: The Curricular Construction of Citizens in Luxembourg in the Long 19th Century," introduces the reader to differentiated kinds of citizenship following the students' expected function in society rather than a consistent Luxembourgian ideal. The author goes back to the dualism between a general secondary education that is cosmopolitan, humanist, and "universal" (bildung) and a practical post-primary school (Volksbildung).

The special feature of this Encounters issue is an interview that Facundo Giuliano (University of Buenos Aires, Argentina) conducted with one of the major thinkers of our time, philosopher Judith Butler (University of California, Berkeley). The interview is entitled "(Re)thinking Education with Judith Butler: A Necessary Meeting between Philosophy and Education." Butler, in her conversation with Giuliano, invites us to face central features of current educational discourses and practices by "interrupting normality" and investing them with an ethically empowering dimension. 